not a tree, and its leaves contain about a twentieth of one per cent of total alkaloids, not " $\frac{1}{2}$ per cent of pure hyoscyamine". Other statements calculated to cause a similar degree of discomfort to botanists occur here and there. Pharmacologists in Britain rarely use cats to standardize digitalis preparations; frogs are generally used. More important, since it involves an analytical principle, it is no longer correct to say that the unit of potency is defined as the quantity of digitalis necessary to stop the heartbeat of an anæsthetized cat or to kill a frog. It is defined as the potency of unit weight of an arbitrarily selected and carefully maintained standard preparation.

This little volume is not a technical handbook, and such inaccuracies are therefore of small account. What is valuable is its method of approach; and the layman who wishes to get a first appreciation of 'Nature's remedies' may do so here along sound lines.

W. O. JAMES

\section{DEVELOPMENT OF SYNTHETIC RUBBER IN THE UNITED STATES}

\section{Buna Rubber}

The Birth of an Industry. By Frank A. Howard. Pp. xii + 307. (New York: D. Van Nostrand Co., Inc.; London : Macmillan and Co., Ltd., 1947.) 21s. net.

$\mathrm{T}$ HE author of this excellent book was, until his retirement in 1945, vice-president of the Standard Oil Co. (N.J.), of which he was principal executive for more than twenty-five years, directing and organising research, technical development and other related activities. He is probably the only man who is in a position to tell the story of the birth and development of the synthetic rubber industry in the United States, and he does so with a detachment which makes one almost forget that he was in the centre of the stage during the whole of the time and that, but for his faith and persistence, synthetic rubber might not have been produced in the United States in time to prevent a calamity.

The book falls naturally into two parts, the first dealing with the period from 1919 until 1939, and the second with the war years.

Co-operation between the Standard Oil Co. and its subsidiaries of America and the I.G. Farbenindustrie of Germany led to the formation in 1929 of a joint company, the Standard-I.G. Company, for the purpose, among other things, of enlarging co-operation in research and development on new products and processes. The final result of this co-operation brought to America the technique of the preparation of Buna $S$, an all-purpose synthetic rubber better known in Britain as $G R-S$, obtained by the copolymerization of butadiene and styrene.

The author tells how he instigated the original approach to the German company and of the liaison work which he afterwards carried out. He had realized in the early 'twenties the enormous potential value (to his country) of an all-purpose synthetic rubber, and his Company tried to interest rubber manufacturers in Buna $S$. Quite naturally, however, they were apathetic, as there were ample supplies of the natural product, and the Government was not prepared to subsidize the necessary development work even after the start of the War in Europe. Howard tells with what sense of urgency he and his colleagues regarded the necessity for the setting up of a synthetic rubber industry and how, in the face of general apathy, his Company decided to erect the necessary plant for the manufacture of Buna $S$ on a small scale.

Even after Pearl Harbour, all their efforts to get this vital material made on a large scale came to nothing time and time again, until the setting up of the Baruch Committee in August 1942; and the resulting appointment of a rubber director with absolute power cleared away all the difficulties, with the result that in a very short time the American synthetic rubber industry was among the largest in the country.

This book is so outstanding that it is unfortunate that, in Great Britain at least, the title may have the effect of limiting its readers to rubber scientists; but it is so well written and tells its thrilling story in such a clear and unprejudiced manner that it should command a much wider audience.

The printing and binding are first-rate and the only errors detected were "Briton" for "Britain" in what may be considered a controversial passage on page 110, and the spelling of the surname of Wallace H. Carothers with a ' $u$ '. The appendix of 51 pages will be much appreciated by those readers who wish to delve more deeply into the history of Buna $S$.

C. W. LONG

\section{PROCESS HEATING IN INDUSTRY}

Industrial Applications of Infrared

By James Doyle Hall. Pp. $x+201$. (New York and London : MeGraw.Hill Book Co., Inc., 1947.) 218.

TN 1938 publicity was first given to the use of 1 radiant heat from electric lamps for the acceler. ation of paint drying. Since then the technique has been developed and extended, and now radiant heating is being used in many different industrial processes. Other sources of heat have been introduced. The present book, written by a lamp engineer, is concerned primarily with the use of electric lamps; and it describes in some detail the properties and design of lamps, reflectors, conveyors and other associated equipment for a very wide range of applications. A most notable feature is the inclusion of more than a hundred illustrations of working installations.

A few pages are devoted to 'radiant cup' gas burners; but no mention is made of the radiant plate type of oven which is quite common in Great Britain ; nor is there any reference to the industrial use of electric heaters with nickel-chromium elements for giving higher intensities of radiation than are possible with lamps.

Within the limitations which the author has set, the book presents the case for radiant heating in a clear, attractive and readily usable manner, and it should be of considerable help to production engineers. It does, however, suffer to some extent from its own limitations. The case for lamp heating might have been stronger if the book had included a balanced comparison with other methods of process heating which are widely used in many of the fields discussed in the book.
M. R. Gavin 